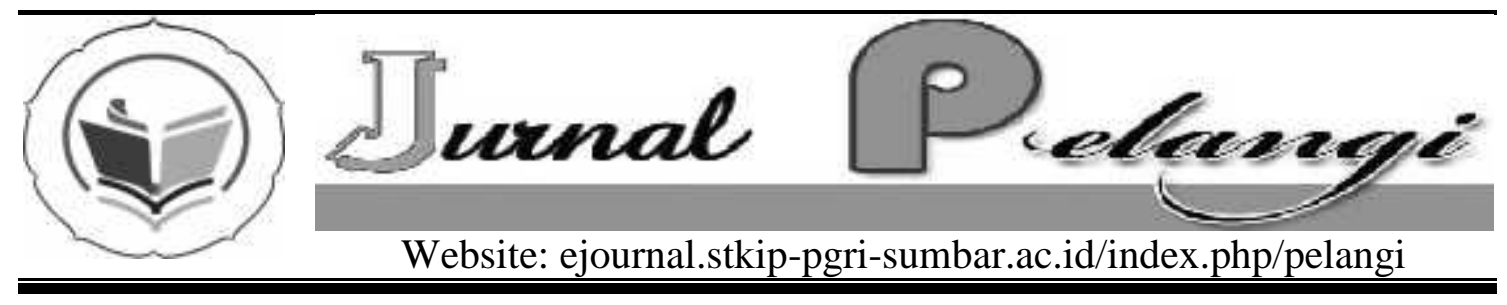

\title{
KEWENANGAN BADAN MUSYAWARAH (BAMUS) NAGARI DALAM PENYELENGGARAAN PEMERINTAHAN NAGARI DI KABUPATEN AGAM
}

\author{
Surya Prahara \\ STKIP PGRI Sumatera Barat \\ takuyaeek@jmail.com
}

\begin{tabular}{l}
\hline INFO ARTIKEL \\
\hline Diterima : \\
Disetujui : \\
\hline Kata Kunci: \\
\hline
\end{tabular}

Bamus

Nagari

Keywords:

BAMUS, Nagari

\begin{abstract}
Abstrak
Fungsi Bamus yaitu menerima aspirasi masyarakat dan menjadi pendamping Wali Nagari dalam mengurus Nagari. Bamus dan Wali Nagari adalah pejabat Nagari yang mampu membimbing dan memakmurkan orang-orang di Nagari tersebut. Lembaga pemerintahan Nagari dinyatakan pada Peraturan Daerah Kabuten Agam nomor 122007 yang berkaitan dengan pemerintah Nagari ini. Peraturan Daerah harus mengatur penyelenggaraan Nagari, Sebaliknya, hal ini menghasilkan beberapa kepentingan yang tumpang tindih antara Bamus dan Wali Nagari. Masalah ini mengarahkan peneliti untuk melakukan penelitian tentang kewenangan Bamus dalam mengelola Nagari di Kabupaten Agam. Temuan penelitian ini membuktikan bahwa jarang Bamus bekerjasama dengan Wali Nagari dalam penyelenggaraan pemerintah. Hal ini terbukti dengan adanya konflik antara Bamus dan Wali Nagari. Keduanya berpikir bahwa mereka memiliki kesempatan yang sama dalam menentukan sistem dan program untuk Nagari.
\end{abstract}

\begin{tabular}{l} 
Abstract \\
\hline The function of BAMUS is to receive people's aspiration and \\
to be Wali Nagari's companion in administering Nagari. \\
BAMUS and Wali Nagari are Nagari's officials who are able \\
to guide and prosper Nagari's people. Institute of Nagari's \\
government is stated on Peraturan Daerah Kabuten Agam \\
number 12, 2007 which is about Nagari's government. PERDA \\
must regulate the organizing of Nagari, in contrary it produces \\
some overlapping interests between BAMUS and Wali Nagari. \\
This problem directs the researcher to conduct a research \\
about the authority of BAMUS in administering Nagari at \\
Kabupaten Agam. The finding of this research prove that it is \\
rarely for BAMUS to corporate with Wali Nagari in organizing \\
the governmence. It is happen because a conflict which is \\
\hline
\end{tabular}


shown that both BAMUS and Wali Nagari fell that they have same opportunity in deciding systems and programs for Nagari.

\section{PENDAHULUAN}

Munculnya Undang-Undang No. 32 Tahun 2004 tentang Pemerintahan Daerah (otonomi) dipandang sebagai bagian dari proses besar demokratisasi. Suatu otonomi bukan final, melainkan langkah awal.Dengan demikian isi dan realisasi isi dari otonomi menjadi sangat penting.Undang-undang No. 32 Tahun 2004 ini membawa sebuah harapan baru bagi perjalanan bangsa ini ke masa ke depan. Hal ini sangatlah wajar karena kebijakan sebelumnya yang notabene melahirkan sebuah kenyataan politis yakni adanya sentralisasi di hampir segala bidang telah membawa dampak yang begitu besar dengan multi krisis sebagai akhir episode sebuah rezim.

Jiwa otonomi daerah sebenarnya adalah untuk membangun kemandirian daerah itu sendiri sekaligus meningkatkan kualitas demokrasi di tingkat lokal.Kinerja demokrasi dapat diukur melalui sejauhmana produk kebijakan-kebijakan yang ada dapat menumbuhkan prakarsa masyarakat dan bukan sebuah ketergantungan.Prinsip otonomi daerah menggunakan prinsip otonomi seluasluasnya dalam arti daerah diberikan kewenangan mengurus dan mengatur semua urusan pemerintahan di luar yang menjadi urusan pemerintah yang ditetapkan dalam Undang-Undang.Daerah memiliki kewenangan membuat kebijakan daerah untuk memberi pelayanan, peningkatan peran serta, prakarsa, dan pemberdayaan masyarakat yang bertujuan pada peningkatan kesejahteraan rakyat.Sebagai perwujudan demokrasi, di desa dibentuk
Badan Permusyawaratan yang dulunya Lembaga Musyawarah Desa (LMD) yang berfungsi menetapkan peraturan desa bersama kepala desa, menampung dan menyalurkan aspirasi masyarakat. Anggota Badan Permusyawaratan adalah wakil dari penduduk desa bersangkutan yang ditetapkan dengan cara musyawarah dan mufakat. Khusus di Sumatera Barat LMD berubah nama menjadi BAMUS (Badan Musyawarah) Nagari

Kedudukan BAMUS (Badan Musyawarah) Nagariadalah sebagai pendamping Wali Nagari dalam menyerap aspirasi rakyat, tetapi dalam pelaksanaan penerapan tugas dan wewenangnya masih terjadi tumpang tindih kepentingan,Pada dasarnya Wali Nagari beserta BAMUS (Badan Musyawarah) Nagarisebagai pejabat pemerintahan dinagari harus dapat menjalankan tugasnya dengan baik untuk membina dan memakmurkan masyarakat yang berada dibawah kepemimpinannya Sedangkan dasar Hukum Pamerntahan Nagari bertitik tolak pada Peraturan Daerah Kabupaten Agam Nomor 12 tahun 2007 tentang Pemerintahan Nagari. Hal inilah yang menjadi dasar bagi penulis untuk mengangkat permasalahan tersebut kedalam sebuah penelitian, sehingga kewenangan BAMUS dalam pelaksanaan pemerintahan nagari pada Kabupaten Agam menjadi jelas sesuai dengan aturan yang berlaku yang telah dibuat oleh Pemerintah. 


\section{METODE PENELITIAN}

Penelitian ini menggunakan penelitian kualitatif yaitu penelitian yang didasaranpada pandangan mereka yang diteliti dengan rinci, dibentuk dengan katakata, gambaran holistik. Alasan penggunaan penelitian kualitatif adalah metod ini menyajikan secara langsung hakikat hubungan antara peneliti dan responden serta penelitian ini lebih dapat menyesuaikan diri dengan banyak penajaman dan terhadap pola-pola nilai yang dihadapi. Penelitian ini di lakukakan pada tiga nagari, yaitu Pada Nagari Koto Malintang Kabupaten Tanjung Raya, Nagari Biaro Gadang Kecama.an Ampek Angkek, dan Nagari Kampung Pinang Kecamatan Lubuk Basung Kabupaten Agam, Adapun alasan pemlikihan lokasi peelitian ini adalah pada ketiga Nagari yang diteliti pada kabupaten Agam terdapat kerancuan daripada fungsi, tugas dan kewenangan perangkat nagari dalam penlelengaraan pemerinttahan Nagari pada Kabupaten Agam.

Beberapa kasus yang terjadi peranan aparatur nagari terutama antara BAMUS, Wali Nagari dan Pemuka Adat sering mengalami tumpang tindih pada penyelenggaraan pemerintahan Nagari, hal ini menimbulkan kerancuan dalam pelaksanaannya yang sehausnya mengacu pada Peraturan Daerah Propinsi dan Peraturan Daerah Kabupaten, khusus Kabupaten Agam terdapat Peraturan Daerah Kabuaten Agam Nomor 12 Tahun 2007 tentang Pemerintahan Nagari.

\section{HASIL DAN PEMBAHASAN}

Bamus Nagari adalah lembaga yang merupakan perwujudan demokrasi dalam penyelenggaraan pemerintahan Nagari sebagai unsur penyelenggara pemerintahan Nagari.Bamus berperan sebagai pembantu dari Wali Nagari.Anggaran Pendapatan dan Belanja Nagari selanjutnya disingkat APB Nagari adalah rencana keuangan tahunan pemerintahan nagari yang dibahas dan disetujui bersama oleh Pemerintah Nagari dan BAMUS Nagari yang ditetapkan dengan Peraturan Nagari Pada dasarnya Bamus berfungsi sebagai pemmbuat Peraturan Nagari yang dirumuskan bersama Wali NagariPemerintahan nagari juga dibentuk berdasarkan persetujuan dari BAMUS, pembentukan pemerintahanbertujuan untuk meningkatkan pelayanan publik guna mempercepat terwujudnya kesejahteraan masyarakat.

Hasil temuan dilapangan dari 3 nagari yang diteliti, BAMUS dan Wali Nagari sangat jarang malakukan koordinasi dalam penyelenggaraan Pemerintahan Nagari, hal ini disebabkan oleh adanya faktor-faktor konflik kesukuan yang cukup kuat. Salah satu permasalahan yang sering ditemukan adalah BAMUS memilih keanggotannya hanya dari satu suku saja, sehingga lebih mementingkankan kepentingan kelompok, meskipun hasil seleksi keanggotaan BAMUS tersebut sesuai dengan Peraturan Daerah Kabupaten Agam yang berlaku.Konflik lain yang terjadi adalah BAMUS tidak menyetujui program Kerja yang diberikan oleh Wali Nagari yang dikarenakan Wali Nagari memiliki suku yang tidak disukai oleh Ketua BAMUS.

Kasus berikutnya adalah dimana kedudukan BAMUS merasa lebih tinggi daripada kedudukan Wali Nagari, sehingga pada penyelenggaraan Pemerintahan Nagari hal tersebut menyebabkan tumpang tindih kepentingan, dimana di satu pihak BAMUS merasa mempunyai kepentingan teradap suatu tndakan namn dilain pihak Wali Nagari merasa mempunyai 
kepentingan yang sama sehingga setiap tindakan dan program yang diambil oelh pemerintahan Nagari sering menemui jalan buntu. Keragaman yang terjadi di Minangkabau terutaa dalam hal kesukuan dapat memicu konflik internal pada sebuah pemerintahan nagari, seharusnya Peraturan daerah kabupaten khususnya Peraturan Daerah Kabuaten Agam Nomor 12 Tahun 2007 tentang Pemerintahan Nagari mampu mengendalikan konflik internal tersebut. Ditambah pula dengan kekurang pahaman aparatur nagari terutama BAMUS dan Wali Nagari yang tidak memahami kedudukan masing-masing bak dalam hal kewenanagan, tugas dan fungsi masingmasing pihak

Berdasarkan Peraturan Kabupaten Agam, adapun tugas BAMUS adalah sebagai pendamping Wali Nagari dalam penyelenggaraan pemerintahan Nagari dan merumuskan bagaimana pelaksanaan teknis dalam penyelenggaraan pemerintahan nagari. BAMUS juga berkewajiban untuk menerima dan memeriksa laporan penyelenggaraan pemerintahan nagari dan laporan pertanggung jawaban dari Wali Nagari dan wajib meginformasikannya kepada masyarakat di Nagari. Hal-hal yang disampaikan pada laporan pertanggung jawaban penyelenggaraan pemerintahan nagari yang diberikan oleh Wali Nagari pada BAMUSmencakup isian tentang

1. Laporan mengenai kinerja Wali Nagari pada peningkatkan kesejahteraan masyarakat, pemeliharaan ketentraman dan ketertiban masyarakat, pelaksanakan kehidupan demokrasi;

2. Laporan pelaksanakaan prinsip tata pemerintahan nagari yang bersih dan bebas dari Kolusi, Korupsi dan Nepotisme;

3. menjalin hubungan kerja dengan seluruh mitra kerja pemerintah nagari;
4. Laporan mengenai kinerja Wali Nagari pada penegakan seluruh peraturan perundang-undangan serta adat setempat;

5. Laporan mengenai kinerja Wali Nagari pada penyelenggaraan administrasi pemerintahan nagari dengan baik dan benar;

6. Laporan mengenai kinerja Wali Nagari pada pelaksanaan dan pertanggungjawabkan pengelolaan keuangan nagari;

7. Laporan mengenai kinerja Wali Nagari pada pelaksanaan urusan yang menjadi kewenangan nagari;

8. Laporan mengenai kinerja Wali Nagari pada pengembangan pendapatan masyarakat dan nagari;

9. Laporan mengenai kinerja Wali Nagari pada pembinaan, pengayoman, pelestarian, nilai-nilai agama, sosial budaya dan adat;

10. Laporan mengenai kinerja Wali Nagari pada pemberdayaan masyarakat dan kelembagaan di nagari;

11. Laporan mengenai kinerja Wali Nagari pada pengembangan potensi sumber daya alam dan melestarikan lingkungan hidup;

12. Laporan mengenai kinerja Wali Nagari pada pergerakan potensi perantau sebagai sumber daya pembangunan nagari;

13. Laporan mengenai kinerja Wali Nagari pada pelaksanaan tugas yang diberikan Pemerintahan Atasan; dan

14. Laporan mengenai kinerja Wali Nagari pada mensukseskan penerimaan Pajak Bumi dan Bangunan serta Pendapatan Asli Daerah.

Wali Nagari pada akhir masa jabatannya melaporkan laporan pertanggung jawaban terhadap kinerja Wali Nagari selama masa jabatannya kepada BAMUS. Laporan pertanggung jawaban 
yang dibuat oleh Wali Nagari tersebut dilaporkan pada satu kali dalam setahun, dan di bahas pada musyawarah yang di laksanakan oleh BAMUS. Hasil dari laporan tersebut akan di informasikan kepada masyarakat, dapat berupa selebaran yang ditempel pada papan pengumuman atau di informasikan secara lisan dalam berbagai pertemuan dengan masyarakat nagari.Laporan akhir jabatan Wali Nagari tersebut akan di evaluasi terlebih dahulu oleh BAMUS yang nantinya akan kembali ditinjau dengan melakukan evaluasi di tingkat kabupaten oleh Bupati sebagai bahan pembinaan lebih lanjut. Laporan pertanggung jawaban akhir jabatan Wali Nagari sebagai penyelenggara pemerintahan nagari tersebut di atur oleh Peraturan Bupati

BAMUS Nagari berfungsi menetapkan Peraturan Nagari bersama WaliNagari, menampung dan menyalurkan aspirasi masyarakat dan Pelaksanaan fungsi diatur dengan tata tertib BAMUS Nagari. Fungsi BAMUS merupakan fungsi legislatif, mirip dengan legislatif daerah. Dasmping itu BAMUS memiliki tugas fungsional berupa membahas dan rancangan peraturan Nagari bersama dengan Wali Nagari.BAMUS merumuskan Peraturan Nagari bersama Wali Nagari, dalam perumusan tersebut BAMUS melibatkan elemen masyarakat dalam pembentukan Peraturan Nagari, agar nantinya Peraturan Nagari tersebut tidak bertentangan dengan keendak dari masyarakat, dan tidak bertentangan pada unsur-unsur Demokrasi.

Dalam melakukan perumusan Peraturan Nagari, BAMUS dan Wali nagari merumuskan Peraturan Nagari, dengan memuat seluruh materi dalam rangka penyelenggaraan pemerintahan nagari dan pemberdayaan masyarakat. Pada tahap perumusan ini BAMUS dan Wali Nagari harus memperhitungkan klausul-klausul yang terdapat di dalam rancang Peraturan
Nagari agar tidak bertentangan dengan peraturan Perundang-Undangan yang lebih tinggi, dan atau bertentangan dengan Undang-Undang dasar 1945.Rancangan Peraturan Nagari tersebut, harus memuat mengenai penjabaran pelaksanaan penyelenggaraan nagari yang lebih bersifat pengaturan.Di dalam perancangan Peraturan nagari masyarakat juga berhak dalam memberikan masukan secara lisan atau secara tertulis.

Setelah peraturan Nagari tadi dirumuskan berdasarkan pertimbanganpertimbangan dan atas keputusan Wali Nagari dan BAMUS maka peraturan nagari tersebut akan di ujikan kelayakannya secara materil oleh BAMUS, dan barulah Peraturan Nagari tersebut di tetapkan dan di ajukan untuk di sahkan oleh Wali Nagari dan BAMUS berdasarkan keputusan Bersama, hal ini sesuai dengan apa yang telah di tetapkan di dalam Peraturan Daerah Kabuaten Agam Nomor 12 Tahun 2007 tentang Pemerintahan Nagari, yaitu pada Pasal 18 ayat (2) huruf c.Hal tersebut mirip seperti fungsi lembaga legisatif daerah lainnya seperti fungsi DPR.Pengujian tersebut berfungsi untuk melihat apakah Peraturan tersebut bertentangan dengan peraturan Perundang-undangan yang lebih tinggi sifatnya atau bertentangan dengan adat setempat, Penyampaian rancangan Peraturan Nagari tersebut harus dilakukan dalam jangka waktu paling lambat 7 (tujuh) hari terhitung sejak tanggal persetujuan bersama.Rancangan Peraturan Nagari yang telah disetujui oleh tersebut disampaikan oleh Pimpinan BAMUS Nagari kepada Walinagari untuk ditetapkan menjadi Peraturan Nagari.

Peraturan Nagari di putus dan di susun secara bersama oleh Wali Nagari dengan BAMUS sebagai wujud implementasi dari desentralisasi dan Otonomi daerah dalam konteks Tugas Pembantuan yang ada di daerah sebagai perpanjangan tangan 
Pemerintahan Pusat di Daerah. Di Kabupaten Agam sendiri pada sistem pemerintahan Nagari penuyusunan Peraturan Nagari dilaksanakan sesuai dengan Peraturan Daerah Kabupaten Agam Nomor 12 Tahun 2007,

Rancangan Peraturan Nagari yang telah mendapatkan pengesahan oleh Wali nagari harus di bubuhi tandatangan Wali nagari dalam jangka waktu paling lambat 30 (tiga puluh) hari sejak diterimanya rancangan Peraturan nagari tersebut. Apabila rancangan Peraturan Nagari yang telah di rumuskan dan mendapatkan pengesahan dari Wali nagari dan BAMUS Nagari tidak ditandatangani berdsarkan ketentuan 30 (tiga puluh) hari setelah rancangan tersebut diterima maka rancangan tersebut secara otomatis akan menjadi Peraturan nagari dan wajib di Undangkan dengan dimuat dalam Berita Daerah. Hal ini sesuai dengan pengaturan yang tertera didalam Peraturan Daerah Kabupaten Agam Nomor 12 tahun 2007 tentang Pemerintahan Nagari, Pasal 81, yang berbunyi:

1. Rancangan Peraturan Nagari sebagaimana dimaksud dalam Pasal 81 ayat (1) dan ayat (2) ditetapkan oleh Walinagari dengan membubuhkan tandatangan dalam jangka waktu paling lambat 30 (tiga puluh) hari sejak diterimanya Rancangan Peraturan Nagari tersebut.

2. Dalam hal rancangan Peraturan Nagari tidak ditetapkan oleh Walinagari dalam waktu sebagaimana dimaksud pada ayat (1) rancangan Peraturan Nagari tersebut menjadi Peraturan Nagari dan wajib diundangkan dengan memuatnya dalam Berita Daerah.

Sahnya sebuah rancangan Peraturan nagari harus terdapat pada lembaran pengesahan kata-kata yang menyataka bahwa rancangan tersebut dinyatakan sah oleh Wali Nagari dan dibubuhkan tanda tangan. Peraturan nagari tersebut dinyatakan mulai berlaku dan mempunyai kekuatan hukum mengikat pada tanggal Peraturan Nagari disahkan. Kecuali ditentukan lain di dalam Peraturan nagari tersebut.

Selain itu BAMUS mempunyai Tugas fungsionalharus berdasarkan pada Peraturan Perundang-undangan yang berlaku, dalam hal ini BAMUS harus menyesuaikan tugasnya dengan Peraturan Daerah Kabupaten Agam Nomor 12 tahun 2007 tentang Pemerintahan Nagari, pada pasal 58i antara lain BAMUS mempunyai kewenangan melaksanakan pengawasan terhadap kinerja Pemerintah Nagari dan pelaksanaan Peraturan Nagari serta Peraturan Walinagari. BAMUS melaksanaan pengawasan terhadap kinerja Pemerintahan Nagari pelaksanaan Peraturan Nagari, dan melakukan pengawasan pada kinerja Wali Nagari. BAMUS berperan sebagai pengawas kinerja dari pelaksanaan Penyelenggaraan Pemerintahan Nagari sebagai perpanjangan tangan dari pemerintahan Kabupaten.Pengawasan yang di lakukan oleh BAMUS harus sesuai dengan peraturan perundang-Undangan yang berlaku sbagai apayung hukum utama dalam pelaksaan Pemerintahan Nagari.

Selain tugas fungsional yang diatur berdasarkan peraturan perundang-undangan yang berlaku, BAMUS mempunyai kewajiban-kewajiban, yang diatur didalam Peraturan Daerah Kabupaten Agam Nomor 12 tahun 2007 tentang Pemerintahan Nagari, pada pasal 62, diantaranya dan mentaati segala peraturan perundangundanganIndonesia Tahun 1945, melaksanakan kehidupan demokrasi dalam penyelenggaraan pemerintahan Nagari dengan menyerap, menampung, menghimpun, dan menindaklanjuti aspirasi masyarakat dan mendahulukan kepentingan umum diatas kepentingan pribadi, 
kelompok dangolongan. BAMUS harus menghormati nilai-nilai sosial budaya dan adat istiadat masyarakat setempat dan menjaga norma dan etika dalam hubungan kerja dengan lembaga kemasyarakatan serta mempertahankan dan memelihara hukum nasional

BAMUS harus melakukan pengusulan dan pemberhentian Wali Nagari.Fungsi pengawasan yang yang dilaksanakan oleh BAMUS tersebut juga berindikasi pada penilaian kinerja terhadap Wali Nagari tersebut.Sehingga BAMUS berhak untuk menentukan apakah kelayakan Wali Nagari.Pengusulan pengangkatan Wali Nagari tentunya harus berdasarkan kriteria yang di tetapkan berdasarkan Peraturan perundang -Undangan yang berlaku.

Dalam rangka penyelenggaraan Pemerintahan Nagari disusun perencanaan pembangunan Nagari sebagai satu kesatuan dalam sistem perencanaan pembangunan Daerah.Perencanaan pembangunan Nagari disusun secara partisipatif oleh Pemerintahan Nagarisesuai dengankewenangannya.Dalam menyusun perencanaan pembangunan Nagari wajib melibatkan lembaga kemasyarakatan Nagari terutama BAMUS. Perencanaan pembangunan Nagari disusun secara berjangka meliputi:

1. Rencana Pembangunan Jangka Menengah Nagari (RPJMN) untuk jangka waktu 5 (lima) tahun;

2. Rencana Kerja Pembangunan Nagari (RKP-Nagari) merupakan penjabaran dari RPJMN untuk jangka waktu 1 (satu) tahun.

Rencana Pembangunan Jangka Menengah Nagari (RPJMN) ditetapkan dengan Peraturan Nagari dan Rencana Kerja Pembangunan Nagari (RKP-Nagari) ditetapkan dalam Keputusan BAMUS Nagari berpedoman pada Peraturan Daerah.Perencanaan pembangunan Nagari didasarkan pada data dan informasi yang akurat dan dapat dipertanggungjawabkan. Data dan informasi mencakup Penyelenggaraan Pemerintahan Nagari, Organisasi dan tata laksana Pemerintahan Nagari, Keuangan Nagari, dan Profil Nagari. Ketentuan lebih lanjut mengenai tahapan, tata cara penyusunan, pengendalian, dan evaluasi pelaksanaan rencana pembangunan Nagari diatur dengan Peraturan Bupati.

\section{KESIMPULAN DAN SARAN}

Hasil temuan dilapangan, BAMUS dan Wali Nagari sangat jarang malakukan koordinasi dalam penyelenggaraan Pemerintahanan, hal ini disebabkan oleh adanya konflik kesukuan yang cukup kuat. Permasalahan yang sering ditemukan adalah BAMUS memilih keanggotannya hanya berasal dari satu suku, sehingga lebih mementingkankan kepentingan kelompok, meskipun hasil seleksi keanggotaan BAMUS tersebut sesuai dengan Peraturan Daerah yang berlaku. Konflik lain yang terjadi adalah BAMUS tidak menyetujui program Kerja yang diberikan oleh Wali Nagari yang dikarenakan Wali Nagari memiliki suku yang tidak disukai oleh Ketua BAMUS. kedudukan BAMUS merasa lebih tinggi daripada kedudukan Wali Nagari, sehingga pada penyelenggaraan Pemerintahan Nagari hal tersebut menyebabkan tumpang tindih kepentingan, dimana di satu pihak BAMUS merasa mempunyai kepentingan teradap suatu tndakan namn dilain pihak Wali Nagari merasa mempunyai kepentingan yang sama sehingga setiap tindakan dan program yang diambil oelh pemerintahan Nagari sering menemui jalan buntu. Berdasarkan PERDA Agam No 27 tugas BAMUS adalah Membahas Rancangan Peraturan Nagari bersama Walinagari, Melaksanakan pengawasan terhadap kinerja Pemerintah Nagari dan pelaksanaan 
Peraturan Nagari serta Peraturan Walinagari, Mengusulkan pengangkatan dan pemberhentian Walinagari, Membentuk panitia pemilihan Walinagari, Menggali, menampung, menghimpun, merumuskan dan menyalurkan aspirasi masyarakat.Menyusun tata tertib BAMUS Nagari

\section{UCAPAN TERIMAKASIH}

Penelitian ini terselenggara atas bantuan dari Yayasan PGRI Padang dan Pemda ampek angkek yang telah bekerjasam dalam pelaksanan penelitian.

\section{DAFTARPUSTAKA}

Alexander Abe, 2005.Perencanaan Daerah Partisipatif. Yogyakarta: Pembaharuan.

Audrey Kahin, 2005, Dari Pemberontakan ke Integrasi: Sumatra Barat dan Politik Indonesia 1926-1998. Yayasan Obor Indonesia.

Indra Ismawan. 2002. Ranjau-Ranjau Otonomi Daerah. Pondok Edukasi.

Jimly,Asshiddiqie, 1998.Pembangunan Hukum Nasional di Abad Globalisasi, Jakarta: Balai Pustaka,

Syaukani Hr, Affan Gaffar, M.Ryass Rasyid, Otonomi Daerah dalam Negara

--------, 1996.Pergumulan Peran Pemerintah dan Parlemen dalam Sejarah: Telaah Perbandingan Konstitusi Berbagai Negara, Jakarta: UI-Press

--------, 2000. “Penataan Kembali Bentuk dan Tata Urut Peraturan Perundang-Undangan Republik Indonesia”, makalah Seminar Nasional tentang Perubahan
Undang-Undang Dasar 1945, Bandar Lampung: Sekretariat Jenderal MPR-RI dan Fakultas Hukum Universitas Indonesia, 24-26 Maret

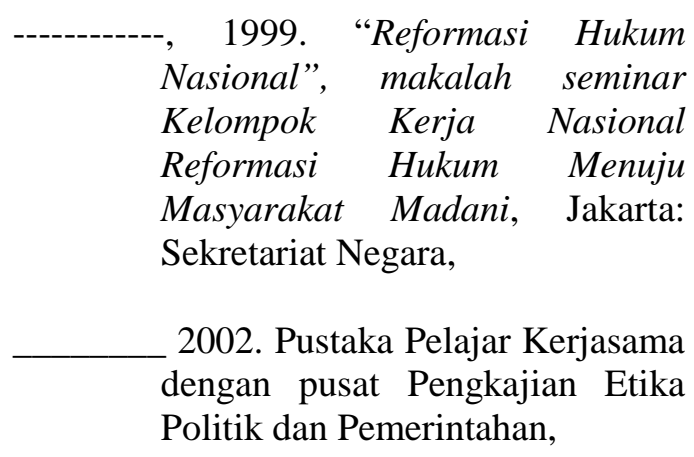

